\title{
PENGARUH PEMBERIAN EKSTRAK DAUN JAMBU BIJI (Psidium guajava $L$ ) TERHADAP GAMBARAN KLINIS DAN LAMA RAWAT INAP PADA PASIEN ANAK DENGAN DEMAM BERDARAH
}

\author{
THE EFFECT OF ADMINISTRATION OF GUAVA LEAF EXTRACT \\ (Psidium guajava L) ON CLINICAL FEATURES AND LENGTH OF STAY \\ IN PEDIATRIC PATIENT WITH DENGUE FEVER
}

\author{
Akrom $^{1}$, Nurcholid Umam Kurniawan ${ }^{2}$, Ery Al Ridho ${ }^{3 *}$ \\ ${ }^{1}$ Departemen Pusat Kajian Informasi Obat, Fakultas Farmasi, Universitas Ahmad Dahlan \\ ${ }^{2}$ Rumah Sakit PKU Muhammadiyah Bantul Yogyakarta \\ ${ }^{3}$ Program Studi Farmasi S2, Program Pasca Sarjana, Universitas Ahmad Dahlan \\ *Penulis korespodensi, e-mail: Ery.almanda@gmail.com
}

\begin{abstract}
ABSTRAK
Demam berdarah dengue (DBD) merupakan penyakit yang disebabkan virus dengue dan sampai saat ini belum ada pengobatan kuratif untuk mengatasi kebocoran plasma. Penelitian sebelumnya melaporkan daun jambu biji berfungsi sebagai penambah trombosit namun pengujian klinis ekstraknya sebagai antidengue masih sangat terbatas. Penelitian ini bertujuan untuk mengetahui pengaruh pemberian ekstrak daun jambu biji (Psidium guajava L) terhadap perbaikan klinis, laboratoris dan lama rawat inap pada pasien DBD di bangsal anak RS PKU Muhammadiyah Bantul Yogyakarta. Design penelitian adalah eksperimental (RCT) dengan penyamaran single blind. Terdapat 2 kelompok yaitu kelompok intervensi yang mendapatkan terapi standar dan ekstrak daun jambu biji dan kelompok kontrol yang mendapatkan terapi cairan standar WHO. Variable yang diukur adalah suhu badan, trombosit, hematokrit dan lama rawat inap. Analisis data menggunakan program SPSS. Hasil penelitian menunjukkan tidak terdapat perbedaan signifikan antar kelompok terhadap jumlah rerata trombosit pada demam hari ke 1 sampai 10 ( $p>0,05)$. Pada parameter hematokrit dan lama rawat inap tidak ditemukan perbedaan yang signifikan antar kelompok dimana nilai $p$ lebih besar dari $0,05(\mathrm{p}>0,05)$. Pada parameter suhu badan juga tidak terdapat perbedaan sgnifikan $(p>0,05)$. Tidak terdapat perbedaan bermakna antara kelompok intervensi dan kontrol pada parameter laboratorium,klinis maupun lama rawat inap.
\end{abstract}

Kata kunci: Ekstrak daun jambu biji, Psidium guajava L, DBD, trombosit, suhu, lama rawat inap

\section{ABSTRACT}

Dengue hemorrhagic fever (DHF) is a disease caused by dengue virus and For this time there are no curative treatment for plasma leakage. The research was reported guava leaves as an addition to platelet function but the clinical testing of guava leaf extract as antidengue still very limited. This study aims to determine the effect of guava leaf extract (Psidium guajava L) to improvement clinical, laboratory and length of stay in DF and DHF patients in the pediatric ward PKU Muhammadiyah Hospital in Bantul. This study is a randomized clinical trial with a single blind. The group is divided into intervention group who received standard therapy + extract of guava leaves (Psidium guajava L) and a control group who received standard fluid therapy WHO. Variable measured was the temperature of the body, trombosit, hematocrit and length of hospitalization. Data analysis was performed using SPSS. There are no significant differences between groups on the mean platelets in 
the febrile days 1 until the fever day $10(p>0.05)$. For the parameters of hematocrit and length of stay was not found significant differences between the groups which the value of $p$ greater than 0.05 ( $p>$ $0.05)$. While on the parameters body temperature not significant differences for fever day 1 until the fever day 10 ( $p>0.05)$. Syrup of guava leaf extract did not give significant differences in hematocrit parameters and length of stay. with a significance value of greater than 0.05 ( $p>0.05)$.

Keywords: Guava leaf extract, Psidium guajava L, DHF, platelets, hematocrit, body temperature, length of stay.

\section{PENDAHULUAN}

Demam berdarah dengue (DBD) merupakan penyakit yang banyak ditemukan di sebagian besar wilayah tropis dan subtropis, terutama Asia Tenggara (Candra, 2010). Host alami DBD adalah manusia, agentnya adalah virus dengue yang terdiri dari 4 serotipe yaitu Den-1, Den-2, Den-3 dan Den-4, ditularkan ke manusia melalui gigitan nyamuk yang terinfeksi (Kurane, 2007). Pada tahun 2014 jumlah penderita DBD yang dilaporkan sebanyak 100.347 kasus dengan jumlah kematian sebanyak 907 orang (Angka kesakitan 39,8 per 100.000 penduduk dan angka kematian $=0,9 \%$ ) (Anonim, 2015). Patofisiologi yang mendasari perbedaan demam dengue dan demam berdarah dengue adalah adanya kebocoran plasma pada demam berdarah dengue akibat inflamasi sistemik yang ditandai dengan tanda-tanda perdarahan, trombositopenia dan sering berakibat pada gangguan hemodinamik dan terjadi syok hipovolemik (Hadinegoro, 2006).

Dalam study in vitro ekstrak etanol daun jambu biji (Psidium Guajava Linn) memiliki aktivitas yang dapat memodulasi sistem imun dan sebagai antiinflamasi menghambat Th2 chemokin melalui penekanan TNF-kB, dengan TNF alpha, interferon-gamma (INF-gamma) maupun mediator inflamasi lain, Nitrit oxide, COX-2 Prostaglandin (PGE2), serta meningkatkan konsentrasi IL-10 yang berfungsi sebagai penghambat aktivitas proinflamatory (Han et al., 2011 dan Jang, 2014). Namun, bukti dan manfaat klinik dari ekstrak daun jambu biji sebagai agen antidengue masih sangat terbatas mengenai bagaimana pengaruh pemberian sirup ekstrak daun jambu biji (Psidi Guajava L) terhadap gambaran klinis dan lama rawat inap pada pasien anak yang menderita demam berdarah dengan harapan dapat membantu menurunkan angka morbiditas dan mortalitas pada pasien demam berdarah.

\section{METODE PENELITIAN}

Uji klinis (Clinical trial) merupakan jenis penelitian eksperimental yang digunakan untuk menelaah hubungan sebab akibat antara variabel bebas dengan variabel tergantung 
dalam periode tertentu. Populasi sumber penelitian ini adalah penderita yang telah terdiagnosa demam berdarah (umur 1- 18 th) berdasarkan kriteria WHO yakni terdiri dari kriteria klinis dan laboratoris. Kriteria klinis:

a. Demam tinggi mendadak tanpa sebab yang jelas berlangsung selama 2-7 hari.

b. Terdapat manifestasi pendarahan, termasuk uji tourniquet positif, ptekiae, ekimosis, epistaksis, pendarahan gusi, hematemesis dan atau melena.

c. Pembesaran hati.

d. Perembesan plasma, ascites dan efusi pleura sampai terjadinya renjatan Kriteria laboratoris:

a) Trombositopenia (kurang dari 100.000/ $\mu$ l).

b) Hemokonsentrasi, dapat dilihat dari peningkatan hematokrit $20 \%$ atau lebih.

Alat dan Bahan

Sirup ekstrak daun jambu biji psidium Guajava dari PT.Dexa Medica dengan dosis anak usia 1-15 tahun 1 sendok takar 5 mL/8 jam, sedangkan dosis anak usia 16 tahun-18 tahun 2-4 sendok takar $5 \mathrm{~mL}$ tiap 8 jam dimana komposisi tiap sendok takarnya mengandung $250 \mathrm{mg}$ ekstrak daun jambu biji.

\section{Jalannya Penelitian}

Dalam penelitian ini dilakukan randomisasi dan penyamaran (blinding) dengan penyamaran single blind yaitu subyek penelitian tidak mengetahui ke dalam kelompok mana subyek dialokasikan (Dahlan, 2010). Penentuan sampel menurut random alokasi ditentukan oleh apoteker di rumah sakit sehingga peneliti tidak mengetahui sampel yang dijadikan kelompok intervensi maupun kelompok kontrol. Pada penelitian ini pasien yang termasuk dalam subjek uji dipilih berdasarkan kriteria yang telah ditetapkan. Total pasien yang terlibat dalam penelitian ini berjumlah 40 orang. Pasien yang terlibat dalam penelitian ini kemudian diminta persetujuannya melalui lembar persetujuan/informed concent kemudian tiap subjek selama perawatannya diberikan terapi tambahan sirup ekstrak daun jambu biji dengan dosis 5 mL tiap 8 jam. Sejumlah 40 pasien yang terlibat dimonitoring berkaitan dengan hasil klinis dan laboratorisnya. Pengambilan darah dilakukan setiap 24 jam. 
Analisis Data

Data demografi dianalisis menggunakan uji frequencies sehingga didapatkan hasil persentase. Uji frequencies digunakan untuk memberikan gambaran ringkas dari sekelompok data dalam suatu tabel frekuensi. Uji statistik untuk data kategorik tidak berpasangan menggunakan uji chi-square sedangkan uji statistik untuk data numerik menggunakan uji parametrik independent T-test (data tidak berpasangan dan distribusi data normal).

Hasil data klinis (suhu badan), laboratoris (hematokrit dan trombosit) serta lama rawat inap dianalisis menggunakan uji parametrik Independent T-test (data tidak berpasangan dan distribusi data normal) dan uji non-parametrik Mann-Whitney (data tidak berpasangan dan distribusi data tidak normal). Perbedaan dinilai bermakna apabila nilai probabilitas $\mathrm{p}<0,05$ dengan tingkat kepercayaan $95 \%$.

\section{HASIL DAN PEMBAHASAN}

Penelitian eksperimental ini bertujuan untuk membandingkan efek pemberian sirup ekstrak daun jambu biji dengan pengobatan standar demam berdarah terhadap nilai laboratoris (trombosit dan hematokrit) dan lama rawat inap pasien terhadap pasien demam berdarah. Karakteristik pasien dalam penelitian ini diantaranya terdapat dalam tabel I.

\section{Analisis Suhu Badan}

Variable dari gambaran klinis lain yang akan diukur pada penelitian ini adalah variabel suhu tubuh pasien saat demam. Hal ini bertujuan untuk melihat efektivitas sirup ekstrak daun jambu biji sebagai terapi pendukung mempercepat proses kesembuhan pasien demam berdarah yang telah mendapatkan terapi standar. Pengukuran suhu badan dilakukan setiap hari selama pasien mendapatkan perawatan di rumah sakit. Tabel II memperlihatkan data perbedaan suhu antara kelompok intervensi dan kelompok control, sedangkan perbandingan grafik suhu pada kelompok intervensi dan kelompok control terlihat pada Gambar 1. 
Tabel I. Karakteristik pasien demam berdarah PKU Muhammadiyah Bantul

\begin{tabular}{|c|c|c|c|}
\hline $\begin{array}{l}\text { Karakteristik } \\
\text { Pasien }\end{array}$ & $\begin{array}{c}\text { Kelompok Terapi } \\
\text { Standar +Sirup } \\
\text { Ekstrak Daun } \\
\text { Jambu Biji }\end{array}$ & $\begin{array}{l}\text { Terapi Standar } \\
\text { (Kontrol) }\end{array}$ & Nilai $p$ \\
\hline Perempuan & $8(33,3 \%)$ & $16(66,7 \%)$ & \\
\hline Laki-laki & $12(75,6 \%)$ & $4(25 \%)$ & 0,02 \\
\hline Usia & 5,8 & 5,05 & 0,50 \\
\hline $\operatorname{Suhu}( \pm$ SD $)$ & $37,24 \pm 0,919$ & $37,55 \pm 0,906$ & 0,315 \\
\hline $\begin{array}{l}\text { Kadar } \\
\text { Trombosit awal } \\
( \pm \text { SD })\end{array}$ & $157900 \pm 31793,5$ & $140925 \pm 28382,3$ & 0,083 \\
\hline $\begin{array}{l}\text { Hematokrit awal } \\
( \pm \text { SD })\end{array}$ & $36,20 \pm 4,008$ & $35,30 \pm 2,962$ & 0,28 \\
\hline Eritrosit ( \pm SD) & $4,70 \pm 0,446$ & $4,19 \pm 0,976$ & 0,093 \\
\hline Leukosit ( \pm SD) & $6,94 \pm 3,321$ & $5,47 \pm 2,819$ & 0,206 \\
\hline Limfosit $( \pm$ SD) & $42,81 \pm 14,863$ & $49,32 \pm 12,405$ & 0,205 \\
\hline Monosit ( \pm SD) & $8,16 \pm 2,156$ & $10,54 \pm 7,961$ & 0,223 \\
\hline Eosinofil $( \pm$ SD) & $1,59 \pm 2,610$ & $0,81 \pm 0,597$ & 0,319 \\
\hline Basofil ( \pm SD) & $0,74 \pm 1,039$ & $0,74 \pm 0,553$ & 0,991 \\
\hline $\begin{array}{l}\text { Hemoglobin } \\
( \pm \text { SD })\end{array}$ & $12,38 \pm 1,496$ & $11,40 \pm 0,948$ & 0,05 \\
\hline $\begin{array}{l}\text { Hari Demam } \\
( \pm \text { SD })\end{array}$ & $3,65 \pm 1,663$ & $4,05 \pm 1,538$ & 0,43 \\
\hline $\begin{array}{l}\text { Keluhan } \\
\text { Demam (n,\%) } \\
\text { Mual/Muntah } \\
\text { Batuk/Pilek } \\
\text { Nyeri Perut } \\
\text { Pendarahan } \\
\end{array}$ & $\begin{array}{l}20(50 \%) \\
4(20 \%) \\
2(10 \%) \\
2(10 \%) \\
2(10 \%) \\
\end{array}$ & $\begin{array}{c}20(50 \%) \\
2(10 \%) \\
8(40 \%) \\
3(15 \%) \\
1(5 \%) \\
\end{array}$ & $\begin{array}{c}0,38 \\
0,032 \\
0,64 \\
0,56 \\
\end{array}$ \\
\hline $\begin{array}{l}\text { Terapi } \\
\text { Antipiretik } \\
\text { Antibiotik } \\
\text { Steroid } \\
\text { Antiulcer } \\
\end{array}$ & $\begin{array}{c}20(100 \%) \\
16(80 \%) \\
3(15 \%) \\
1(5 \%) \\
\end{array}$ & $\begin{array}{c}19(95 \%) \\
18(90 \%) \\
1(5 \%) \\
- \\
\end{array}$ & $\begin{array}{c}0,5 \\
0,17 \\
0,32 \\
0,33 \\
\end{array}$ \\
\hline $\begin{array}{l}\text { Cairan } \\
\text { Antiemetik } \\
\text { Dekongestan } \\
\text { Probiotik }\end{array}$ & $\begin{array}{c}20(100 \%) \\
2(10 \%) \\
6(30 \%) \\
2(10 \%)\end{array}$ & $\begin{array}{c}20(100 \%) \\
0 \\
17(85 \%) \\
2(10 \%)\end{array}$ & $\begin{array}{c}0,5 \\
0.16 \\
0,01 \\
0,95\end{array}$ \\
\hline $\begin{array}{l}\text { uji Chi-square } \\
\text { uji T-test } \\
\text { unpaired } \\
\text { significant p value }\end{array}$ & & & \\
\hline
\end{tabular}


Tabel II. Perbedaan efektivitas sirup ektrak daun jambu biji dan terapi standar terhadap suhu badan pasien DBD anak di RS PKU Muhammadiyah Bantul

\begin{tabular}{|c|c|c|c|}
\hline \multirow[b]{2}{*}{ Hari Demam } & \multicolumn{2}{|c|}{$\begin{array}{ll}\text { Suhu Badan } \\
\end{array}$} & \multirow[b]{2}{*}{ Nilai $p$} \\
\hline & $\begin{array}{c}\text { Terapi Standar + } \\
\text { Sirup Ekstrak Daun } \\
\text { Jambu Biji }\end{array}$ & $\begin{array}{l}\text { Terapi Standar } \\
\text { (Kontrol) }\end{array}$ & \\
\hline Demam hari ke-1 & $36,7 \pm 0,577$ & $37 \pm 0,00$ & 0,66 \\
\hline $\begin{array}{c}M e a n \pm S D \\
\text { n }(\%)\end{array}$ & $3(66,7 \%)$ & $1(33,3 \%)$ & \\
\hline Demam hari ke-2 & $37 \pm 0,707$ & $37,07 \pm 1,102$ & 0,93 \\
\hline $\begin{array}{c}M e a n \pm S D \\
n(\%)\end{array}$ & $5(62,5 \%)$ & $3(37,5 \%)$ & \\
\hline Demam hari ke-3 & $36,86 \pm 0,602$ & $37,44 \pm 1,079$ & 0,16 \\
\hline $\begin{array}{c}M e a n \pm S D \\
\text { n }(\%)\end{array}$ & $9(47,4 \%)$ & $10(52,6 \%)$ & \\
\hline Demam hari ke-4 & $37,28 \pm 1,103$ & $37,55 \pm 1,161$ & 0,57 \\
\hline $\begin{array}{c}M e a n \pm S D \\
\text { n }(\%)\end{array}$ & $12(50 \%)$ & $12(50 \%)$ & \\
\hline Demam hari ke-5 & $37,14 \pm 0,74$ & $37,09 \pm 0,606$ & 0,84 \\
\hline $\begin{array}{c}M e a n \pm S D \\
\text { n }(\%)\end{array}$ & $14(50 \%)$ & $14(50 \%)$ & \\
\hline Demam hari ke-6 & $36,8 \pm 0,684$ & $37,11 \pm 0,718$ & 0,31 \\
\hline $\begin{array}{c}M e a n \pm S D \\
\text { n }(\%)\end{array}$ & $15(46,9 \%)$ & $17(53,1 \%)$ & \\
\hline Demam hari ke-7 & $36,55 \pm 0,522$ & $37 \pm 0,679$ & 0,07 \\
\hline $\begin{array}{c}M e a n \pm S D \\
\text { n }(\%)\end{array}$ & $11(44 \%)$ & $14(56 \%)$ & \\
\hline Demam hari ke-8 & $36,78 \pm 0,441$ & $36,9 \pm 0,568$ & 0,60 \\
\hline $\begin{array}{c}M e a n \pm S D \\
\text { n }(\%)\end{array}$ & $9(47,4 \%)$ & $10(52,6 \%)$ & \\
\hline Demam hari ke-9 & $37 \pm 1,000$ & $36,8 \pm 0,690$ & 0,83 \\
\hline $\begin{array}{c}M e a n \pm S D \\
\text { n }(\%)\end{array}$ & $3(30 \%)$ & $7(70 \%)$ & \\
\hline Demam hari ke-10 & $37,5 \pm 2,121$ & $36,8 \pm 0,836$ & 0,72 \\
\hline $\begin{array}{c}M e a n \pm S D \\
\text { n }(\%)\end{array}$ & $2(28,6 \%)$ & $5(71,4 \%)$ & \\
\hline $\begin{array}{l}\text { uji T-test unpaired } \\
\text { significant p value }\end{array}$ & & & \\
\hline
\end{tabular}

Dari table II dapat terlihat bahwa suhu demam pada hari ke 1 sampai dengan hari ke 10 pada kelompok intervensi dan kontrol tidak terdapat perbedaan yang signifikan $(p>0,05)$. 


\section{Grafik Suhu Intervensi dan Kontrol}

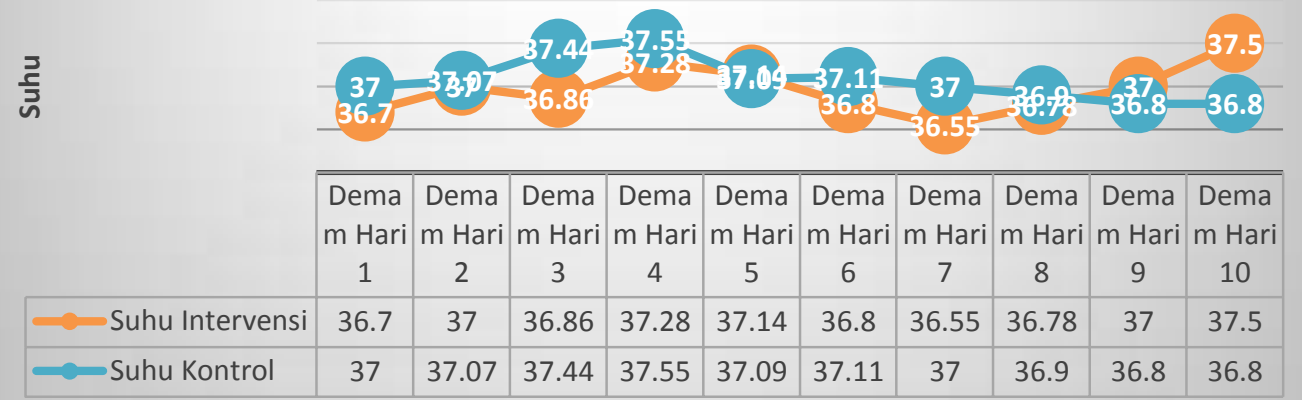

Gambar 1. Perbandingan grafik suhu pada kelompok intervensi dan kelompok kontrol

Ekstrak daun jambu biji memiliki potensi membantu menurunkan demam. Ekstrak daun jambu biji diketahui mengandung senyawa quercetin yang memiliki mekanisme sebagai antiinflamasi yang dapat menghambat sitokin proinflamasi seperti TNF-alfa, produksi prostaglandin melalui jalur siklooksigenase (Anonim, 2017 dan Han et al., 2011). Selain itu quercetin dapat meningkatkan konsentrasi IL-10 yang berfungsi sebagai sitokin antiinflamatory (Shabbir, 2016 dan Nambuso, 2016).

\section{Analisis Trombosit dan Hematokrit}

Trombosit dan hematokrit merupakan parameter sederhana yang biasa digunakan untuk menilai keberhasilan terapi pada pasien demam berdarah, karena pendarahan yang terjadi pada pasien demam berdarah merupakan konsekuensi dari terjadinya trombositopenia dan disfungsi platelet (WHO, 2009). Tabel III dan gambar 2 menunjukkan hasil perbandingan kadar trombosit dan hematokrit dari penggunaan sirup ekstrak daun jambu biji dan terapi standar.

Dari tabel III dan grafik 2 terlihat bahwa terdapat perbedaan rerata trombosit pada kelompok intervensi dibandingkan dengan kelompok kontrol namun secara statistik tidak terdapat perbedaan yang bermakna dimana nilai probabilitas $(p)$ yang didapatkan masih di atas 0,05 $(p>0,05)$. Begitu pula untuk perbandingan hematokrit antara kelompok intervensi dan kelompok kontrol tidak terdapat perbedaan yang signifikan dimana nilai $p$ antara kelompok intervensi dan kontrol di atas 0,05. 
Tabel III. Perbedaan efektivitas sirup ekstrak daun jambu biji dan terapi standar terhadap rerata trombosit dan hematokrit

\begin{tabular}{|c|c|c|c|}
\hline Hari Demam & $\begin{array}{c}\text { Intervensi Terapi } \\
\text { Standar +Ekstrak } \\
\text { daun jambu Biji }\end{array}$ & $\begin{array}{c}\text { Terapi } \\
\text { Standar (Kontrol) }\end{array}$ & Nilai $p$ \\
\hline $\begin{array}{c}\text { Demam Hari ke } 1 \\
\text { Trombosit }\end{array}$ & $\begin{array}{c}151,67 \pm 21501 \\
3(75 \%)\end{array}$ & $\begin{array}{c}135 \\
1(25 \%)\end{array}$ & 0,57 \\
\hline $\begin{array}{c}\mathrm{N}(\%) \\
\text { Hematokrit } \\
\mathrm{N}(\%)\end{array}$ & $\begin{array}{c}37,33 \pm 6,807 \\
3(75 \%)\end{array}$ & $\begin{array}{c}33,5 \\
1(25 \%)\end{array}$ & 0,67 \\
\hline $\begin{array}{c}\text { Demam Hari ke } 2 \\
\text { Trombosit }\end{array}$ & $\begin{array}{c}183,4 \pm 69568 \\
5(62,5 \%)\end{array}$ & $\begin{array}{c}146,33 \pm 189,03 \\
3(37,5 \%)\end{array}$ & 0,41 \\
\hline $\begin{array}{c}\mathrm{N}(\%) \\
\text { Hematokrit } \\
\mathrm{N}(\%)\end{array}$ & $\begin{array}{c}35,4 \pm 3,782 \\
5(62,5 \%)\end{array}$ & $\begin{array}{c}34,10 \pm 3,180 \\
3(37,5 \%)\end{array}$ & 0,63 \\
\hline $\begin{array}{c}\text { Demam Hari ke } 3 \\
\text { Trombosit }\end{array}$ & $\begin{array}{l}188,6 \pm 667,4 \\
8(44,4 \%)\end{array}$ & $\begin{array}{c}144,45 \pm 401,9 \\
10(55,6 \%)\end{array}$ & 0,10 \\
\hline $\begin{array}{c}\mathrm{N}(\%) \\
\text { Hematokrit } \\
\mathrm{N}(\%)\end{array}$ & $\begin{array}{l}36 \pm 3,674 \\
8(44,4 \%)\end{array}$ & $\begin{array}{c}34,59 \pm 2,744 \\
10(55,6 \%)\end{array}$ & 0,35 \\
\hline $\begin{array}{c}\text { Demam Hari ke } 4 \\
\text { Trombosit }\end{array}$ & $\begin{array}{c}163,3 \pm 361,08 \\
11(50 \%)\end{array}$ & $\begin{array}{c}135,95 \pm 310,8 \\
11(50 \%)\end{array}$ & 0,07 \\
\hline $\begin{array}{c}\mathrm{N}(\%) \\
\text { Hematokrit } \\
\mathrm{N}(\%)\end{array}$ & $\begin{array}{c}36,18 \pm 3,219 \\
11(50 \%)\end{array}$ & $\begin{array}{c}36,44 \pm 3,034 \\
11(50 \%)\end{array}$ & 0,85 \\
\hline $\begin{array}{c}\text { Demam Hari ke } 5 \\
\text { Trombosit }\end{array}$ & $\begin{array}{c}153,2 \pm 242,7 \\
12(46,2 \%) \\
\end{array}$ & $\begin{array}{c}138,07 \pm 372,4 \\
14(53,8 \%) \\
\end{array}$ & 0,23 \\
\hline $\begin{array}{c}\mathrm{N}(\%) \\
\text { Hematokrit } \\
\mathrm{N}(\%)\end{array}$ & $\begin{array}{l}35,5 \pm 4,011 \\
12(46,2 \%)\end{array}$ & $\begin{array}{c}36 \pm 2,499 \\
14(53,8 \%)\end{array}$ & 0,70 \\
\hline $\begin{array}{c}\text { Demam Hari ke } 6 \\
\text { Trombosit } \\
\text { N }(\%) \\
\text { Hematokrit } \\
\text { N }(\%)\end{array}$ & $\begin{array}{c}154,8 \pm 272,1 \\
15(48,4 \%) \\
34,9 \pm 4,011 \\
15(48,4 \%)\end{array}$ & $\begin{array}{c}138,9 \pm 308.2 \\
16(51,6 \%) \\
35,04 \pm 3,158 \\
16(51,6 \%)\end{array}$ & 0,94 \\
\hline $\begin{array}{c}\text { Demam Hari ke } 7 \\
\text { Trombosit } \\
\text { N(\%) } \\
\text { Hematokrit } \\
\mathrm{N}(\%)\end{array}$ & $\begin{array}{c}148,4 \pm 375,3 \\
11(50 \%) \\
34,73 \pm 4,777 \\
11(50 \%)\end{array}$ & $\begin{array}{c}136,9 \pm 287,4 \\
11(50 \%) \\
34,49 \pm 2,928 \\
11(50 \%)\end{array}$ & 0,42 \\
\hline $\begin{array}{c}\text { Demam Hari ke } 8 \\
\text { Trombosit } \\
\mathrm{N}(\%) \\
\text { Hematokrit } \\
\mathrm{N}(\%)\end{array}$ & $\begin{array}{c}156,3 \pm 441,1 \\
9(52,9 \%) \\
35,4 \pm 4,216 \\
9(52,9 \%)\end{array}$ & $\begin{array}{c}156,5 \pm 331,5 \\
8(47,1 \%) \\
34,68 \pm 3,435 \\
8(47,1 \%)\end{array}$ & 0,99 \\
\hline $\begin{array}{c}\text { Demam Hari ke } 9 \\
\text { Trombosit } \\
\mathrm{N}(\%) \\
\text { Hematokrit } \\
\mathrm{N}(\%)\end{array}$ & $\begin{array}{c}154,8 \pm 8282,1 \\
3(50 \%) \\
39,8 \pm 4,801 \\
3(50 \%)\end{array}$ & $\begin{array}{c}180 \pm 490,3 \\
3(50 \%) \\
35,3 \pm 4,509 \\
3(50 \%)\end{array}$ & 0,36 \\
\hline
\end{tabular}




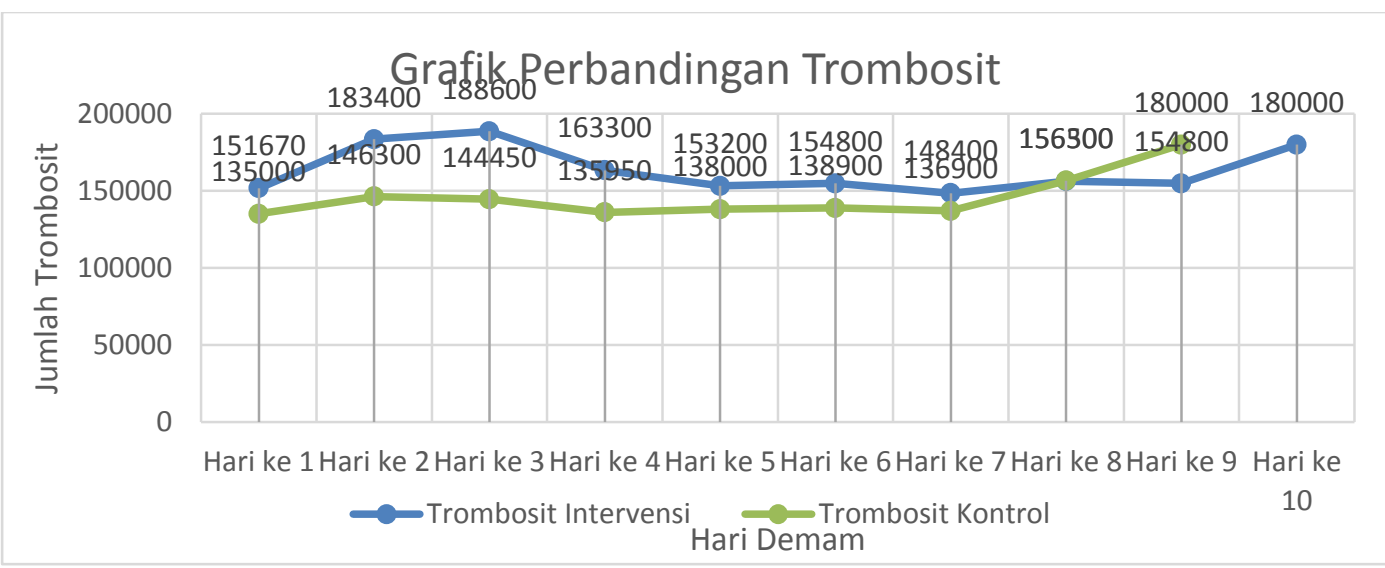

Gambar 2. Grafik trombosit pada kelompok intervensi dan kelompok control

Penelitian oleh Nasiruddin tahun 2005, mengenai "pengaruh pemberian ekstrak daun jambu biji terhadap peningkatan jumlah trombosit pada kasus demam berdarah dengue pada anak", double-blind randomized controlled trial, di RSUD dr. Soetomo Surabaya, Maret 2004-Maret 2005, menunjukkan bahwa kelompok yang diberikan ekstrak daun jambu biji lebih cepat meningkatkan jumlah trombosit $>100.000 / \mu \mathrm{L}$ dibandingkan kelompok kontrol.

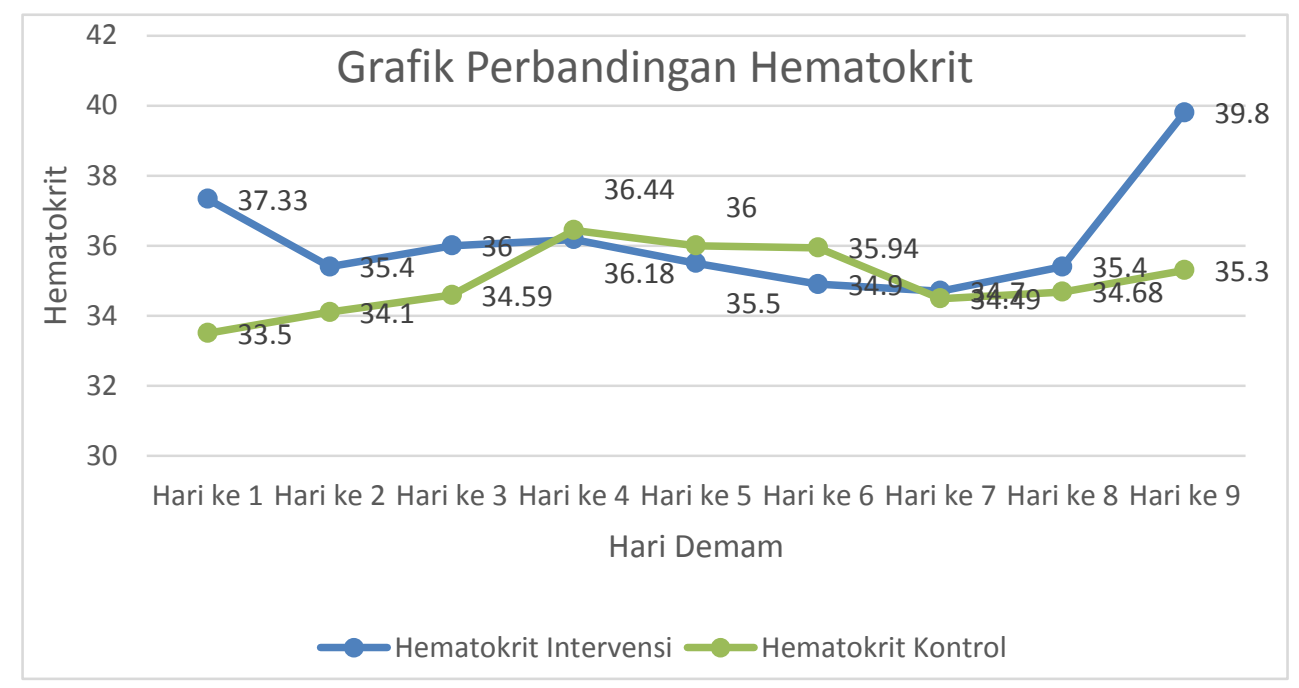

Gambar 3. Grafik trombosit pada kelompok intervensi dan kelompok kontrol

Beberapa mekanisme yang memungkinkan sirup ekstrak daun jambu biji dapat digunakan sebagai terapi pendukung demam berdarah diantaranya karena memiliki aktivitas sebagai antivirus, antiinflamasi, penambah trombosit dan sebagai antioksidan. Sebagai antivirus dengue dimana demam berdarah merupakan demam yang disebabkan oleh infeksi 
virus dengue. Virus dengue termasuk dalam genus flavivirus family flaviviridae. Virus ini berintikan materi genetik RNA, sehingga target kerja dari obat yang digunakan sebagai antivirusnya adalah obat yang dapat menginhibisi replikasi materi genetik RNA (POM RI, 2004). Menurut Saptawati (2017), dalam penelitiannya melaporkan bahwa ekstrak daun jambu biji memiliki aktivitas antivirus. Sebagai antiinflamasi yaitu quersetin dan kaemferol memberikan efek antiinflamsi melalui penghambatan jalur lipooksigenase, siklooksigenase, NF-kB, TNF-a,INF- $\gamma$, IL-6, chemokin Interleukin-8, monosit chemoattractant protein-1 dan meregulasi dan aktivasi ekspresi sel $\mathrm{T}$ normal. Selain sebagai antiinflamasi yang poten kaempferol bekerja dengan menghambat ekspresi INOS (inducible nitrit oxide synthase) yang berfungsi sebagai pertanda meningkatnya kejadian inflamsi (Hamalainen, 2007; Pubchem NCBI, 2017 dan Choi, 2012). Quercetin dapat meningkatkan konsentrasi IL-10 yang berfungsi sebagai sitokin antiinflamatory (Shabbir, 2016 dan Nambuso, 2016).

Ekstrak daun jambu biji mengandung senyawa trombinol yang dapat membantu proses hematopoiesis trombosit yaitu dengan cara menstimulasi pembentukan sitokin GM-CSF yang dibutuhkan untuk proses pembentukan trombosit (Guntur, 2017). Dalam penelitian yang dilakukan oleh Soeprapto Maat (2004) didapatkan bahwa peningkatan jumlah trombosit terjadi melalui mekanisme peningkatan jumlah sitokin, terutama GM-CSF, IL-3 sehingga dapat meningkatkan jumlah trombosit dalam darah. Menurut Nasirudin (2005), bahwa ekstrak daun jambu biji dapat meningkatkan kadar GMCSF lebih tinggi dibandingkan kelompok kontrol.

Sebagai antioksidan keadaan stress oksidativ dipicu oleh perkembangan virus dengue. Mekanisme pemusnahan antigen asing/virus dengue dapat berlangsung dalam proses oksidatif yang artinya melibatkan oksigen dalam proses destruksi tersebut, contohnya destruksi mikroba intraselular yang terjadi oleh karena di dalam sel fagosit, monosit dan polimorfonuklear terdapat berbagai bahan antimicrobial seperti hydrogen peroksidase $\left(\mathrm{H}_{2} \mathrm{O}_{2}\right)$ dan mieloperoksidase (Bartrawidjaja, 2014). Ekstrak daun jambu biji mengandung sejumlah senyawa antioksidan seperti vitamin $\mathrm{C}$ dan vitamin $\mathrm{E}$ dan beberapa flavonoidnya (Agustinus, 2009). Mekanisme antioksidan dapat mencegah terjadinya proses stress oksidativ akibat infeksi virus dengue sehingga dapat mencegah trombositopenia pada pasien demam berdarah. Penelitian lain tentang manfaat antioksidan sebagai terapi suportif pada demam berdarah pernah dilakukan oleh Prasanna dkk pada tahun 2013, hasilnya adalah bahwa pemberian 
vitamin E $400 \mathrm{mg}$ dan vitamin C $500 \mathrm{mg}$ signifikan meningkatkan angka trombosit dan mempercepat masa penyembuhan pasien demam berdarah (Prasanna, 2013).

\section{Lama Rawat Inap ( Length of Stay)}

Variabel berikutnya yang dianalisis adalah lamanya waktu perawatan pasien saat di rumah sakit (Length of Stay). Lama rawat inap adalah lamanya perawatan pasien oleh dokter dari mulai masuk hingga keluar rumah sakit dan tercatat dalam rekam medik pasien, dihitung mulai menggunakan ekstrak daun jambu biji sampai pasien dinyatakan sembuh dan dibolehkan pulang oleh DPJ pasien dan tercatat di rekam medik pasien. Tabel IV menunjukkan perbedaan lamanya rawat inap antara pasien pada kelompok perlakuan yang mendapatkan terapi standar + ekstrak daun jambu biji dan kelompok kontrol yang hanya mendapatkan terapi standar.

Tabel IV. Perbedaan efektivitas kelompok intervensi dan kelompok kontrol terhadap luaran terapi lama rawat inap pasien DF/DHF anak.

\begin{tabular}{lccc}
\hline Kelompok & N & $\begin{array}{c}\text { Lama rawat inap } \\
\text { Mean } \pm \text { SD }\end{array}$ & Nilai $\boldsymbol{p}$ \\
\hline $\begin{array}{l}\text { Standar WHO } \\
\text { (Kontrol) }\end{array}$ & 20 & $4,80 \pm 1,240$ & 0,12 \\
$\begin{array}{l}\text { Standar+ekstrak } \\
\text { daun jambu biji }\end{array}$ & 20 & $4,20 \pm 1,196$ & \\
\hline $\begin{array}{l}\text { uji } \boldsymbol{T} \text {-test unpaired } \\
\text { significant } \text { palue }\end{array}$ & & & \\
\hline
\end{tabular}

Dari tabel IV dapat disimpulkan bahwa rerata lama rawat inap pada pasien kelompok kontrol adalah 4,80 hari dan rerata lama rawat inap pada pasien kelompok intervensi yang mendapatkan terapi standar+ekstrak daun jambu biji adalah 4,20 hari. Secara statistik tidak terdapat perbedaan lama rawat inap antara kelompok kontrol dan kelompok intervensi dimana nilai $p$ 0,12 (p>0,05). Penelitian serupa pernah dilakukan oleh Abdur Rosyid et al., 2017, dengan hasil bahwa rata-rata lama rawat inap untuk pasien yang mendapatkan ekstrak daun jambu biji 4-5 hari dan tidak berbeda signifikan dengan kelompok kontrol.

\section{KESIMPULAN}

Tidak terdapat perbedaan yang bermakna pada parameter laboratorium,klinis maupun lama rawat inap antara kelompok intervensi dan kontrol. 


\section{DAFTAR PUSTAKA}

Abdur Rosyid, Willi Wahyu Timur, Pramadevi Almira Minerva Vania, 2017, Perbandingan lama rawat inap pengobatan demam berdarah dengue pada anak-anak menggunakan obat suportif yang mengandung ekstrak daun jambu biji (psidium guajava linn.) dan obat imunomodulator. Borneo Journal of Pharmascientech, vol 01, no. 02.

Agustinus, 2009. Studi hematologis potensi metabolic jambu biji merah (Psidium guajava l.) pada penderita demam berdarah dengue. Program Studi Biokimia Fakultas Matematika dan Ilmu Pengetahuan Alam Institut Pertanian Bogor

Anonim, 2004. POM RI; Keterangan Pers No.Kh.00.01.241.259.III.2004 tentang hasil penelitian pengembangan ekstrak daun jambu biji (Psidium Guajava) menjadi fitofarmaka anti demam berdarah.

Anonim, 2015. Profil Kesehatan Indonesia 2014. Kementerian Kesehatan RI.

Anonim, 2017. http://www.pubchem.20quercetin/quercetin\%20_\%20C15H10O7\%20\%20PubChem.html. diakses tanggal 12 november 2017

Baratawidjaja, K. G. 2014. Imunologi Dasar. Jakarta: Fakultas Kedokteran, Universitas Indonesia.

Candra, A., 2010. Demam Berdarah Dengue: Epidemiologi, Patogenesis, dan Faktor Risiko Penularan.FK Undip Semarang. Aspirator, Vol. 2 No. 2 Tahun 2010 : $110-11$

Choi Jae Ho, Bong Hwan Park, Hyung Gyun Kim,Yong Pil Hwang, Eun Hee Han, Jong Kwon Seo,Young Chul Chung, Hye Gwang Jeong, 2012. Inhibitory effect of Psidium guajava water extract in the development of 2,4-dinitrochlorobenzene-induced atopic dermatitis in NC/Nga mice. Elsevier. Food and Chemical Toxicology, 50, 2923-2929

Dahlan, S.M. 2010. Membaca dan Menelaah Jurnal Uji Klinis. Jakarta: Salemba Medika.

Guntur Berlian, Olivia Mayasari Tandrasasmita, Raymond Rubianto Tjandrawinata. 2017. Trombinol, a bioactive fraction of Psidium guajava, stimulates thrombopoietin expression in HepG2 cells. Section of Molecular Pharmacology Dexa Laboratories of Biomolecular Sciences, Dexa Medica, Industri Selatan V, Block PP No. 7, Jababeka Industrial Estate II, Cikarang, West Java 17550, Indonesia. Asian Pac J Trop Biomed 2017; 7(5): 437-442

Hadinegoro SRH, Soegiyanto S, Wuryadi S, Suroso T. 2006. Tatalaksana demam berdarah dengue. Jakarta : Departemen Kesehatan RI.:2-3.

Han, E.H., Hwang, Y.P., Kim, H.G., Park, J.H., Choi, J.H., Im, J.H., Khanal, T., Park, B.H., Yang, J.H., Choi, J.M., Chun, S.S., Seo, J.K., Chung, Y.C., Jeong, H.G., 2011, Ethyl 
acetate extract of Psidium guajava inhibits IgE-mediated allergic responses by blocking FceRI signaling. Food Chem. Toxicol. 49, 100-108.

Kurane. I., 2007, Dengue Hemorrhagic Fever With Special Emphasis on Immunopathogenesis, Comparative Immunology, Microbiology and Infectious Diseases, Volume 30 issues 5-6, pages 329-340.

Mari Hamalainen, Riina Nieminen, Pia Vuorela, Marina Heinonen, and Eeva Moiianen, 2007. Anti-Inflammatory Effects of Flavonoids: Genistein, Kaempferol, Quercetin, and Daidzein Inhibit STAT-1 and NF-KB Activations, Whereas Flavone, Isorhamnetin, Naringenin, and Pelargonidin Inhibit only NF-KB Activation along with Their Inhibitory Effect on iNOS Expression and NO Production in Activated Macrophages. Hindawi Publishing Corporation, Mcdialors of Inflammation, Volume 2007, Article ID 45673, 10 pages doi:1 O.I 155/2007/45673.

Mi Jang, Seung-Weon Jeong, Somi K. Cho, Kwang Seok Ahn, Jong Hyun Lee, Deok Chun Yang, and Jong-Chan Kim .2014. Anti-Inflammatory Effects of an Ethanolic Extract of Guava ( Psidium guajava L.) Leaves In Vitro and In Vivo. Department of Food Analysis $\&$ Standardization, Korea Food Research Institute, Seongnam, Gyeonggi-do, Korea.

Nombuso Valencia Pearl Mkhize, Lihle Qulu, and Musa Vuyisile Mabandla., 2016. The effect of quercetin on pro and anti inflamatory cytokines in a prenatally stressed rat model of febrile seizure. Journal of experimental Neuroscience, Volume 11-18.

Nasiruddin, M. 2005. Pengaruh pemberian esktrak daun jambu biji terhadap peningkatan jumlah trombosit pada kasus demam berdarah dengue pada anak. Penelitian Karya Ilmiah Akhir. Fakultas Kedokteran Universitas Airlangga.

Prasanna Chandra, Hemant Sharma, Akash Gupta and Yogesh Rai1. 2013. Role of antioxidant vitamin e and $\mathrm{c}$ on platelet levels in dengue fever. international journal of basic and applied medical sciences issn: $2277-2103$ (online) an online international journal available at http://www.cibtech.org/jms.htm 2013 vol. 3 (1) january-april, pp.287-291/chandra et al.

Sabir dan Wahyuni, 2011. Karakteristik Penderita Demam Berdarah Dengue (DBD) di Rumah Sakit Wahidin Sudirohusodo Makassar Periode Januari - Desember 2010.Inspirasi, No.XIV.

Saptawati, L., Ratih Puspita Febrinasari, Ratih Dewi Yudhani, Hudiyono, Agya Ghilman Faza, Sarah Luthfiani, Hutami Sri Ummiyati, T. Mirawati Sudiro, Beti Ernawati Dewi. 2017. In vitro study of eight Indonesian plants extracts as anti Dengue virus. Department of Microbiology, Faculty of Medicine, University of Sebelas Maret, Surakarta, Central Java. Vol. 8, No. 1.

Suprapto M. 2004. Penelitian dan pengembangan produk fitofarmaka dari daun jambu biji (Psidium guajava L) untuk tujuan terapi demam berdarah dengue berdasarkan data 
preklinik, toksisitas dan percobaan klinik. Laporan Tahun I, (Standarisasi,formulasi, uji toksisitas,uji bioaktivitas preklinik).

WHO. 2009. Dengue Guideline for Diagnosis, Treatment,Prevention, and Control, (New edition), France :WHO. 